\title{
Treating valvular heart disease has never been one size fits all
}

\author{
Hersh Maniar, MD
}

See related article on pages e29-30.

The case report by Capestro and colleagues in this issue of the Journal illustrates the many therapeutic options cardiac surgeons now have at their disposal to treat complex valvular heart disease. ${ }^{1}$ Capestro and colleagues have described a difficult patient scenario that occurs commonly after homograft implantation. The rate of structural valve deterioration with homografts approaches nearly $40 \%$ at 10 years, and the accompanying extensive calcification of these prostheses complicates reoperative aortic valve replacement surgery by predisposing toward paravalvular leaks, the implantation of small prostheses, and perioperative stroke. ${ }^{2}$ Capestro and colleagues are to be commended for their thoughtful preprocedural planning, for obtaining advanced computed tomographic imaging, and for considering newer technologies at their disposal.

The options for this type of patient are multiple and range from a Bentall procedure to valve-in-valve procedures, either directly with a surgical prosthesis or through transcatheter aortic valve replacement (TAVR). Each of these therapies, of course, has its own specific advantages and weakness. ${ }^{3,4}$ Whereas Bentall procedures in this setting have had reported good outcomes at some centers, the overall results are mixed, with significant morbidity and mortality. Similarly, the combination of a calcified root and annulus without leaflet calcification poses technical complications for any valve-in-valve procedure with either surgical or TAVR prostheses. Capestro and colleagues have chosen to implement the strategy of "sutureless in the stentless," first described by Villa and colleagues in $2013,{ }^{5}$ and implanted a sutureless aortic valve prosthesis, the Perceval $\mathrm{S}$ (Sorin Group, Milan, Italy), within the degenerated homograft. This newer, less commonly reported strategy obviates the need for placing sutures within a calcified aortic annulus and eliminates the risk of malpositioning or embolization that can occur with TAVR in this setting because of the paucity of fluoroscopic anatomic landmarks of homografts and the difficulties in appropriately sizing and anchoring a TAVR prosthesis without bulky, calci-

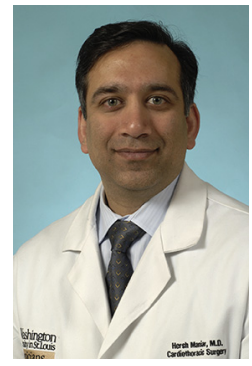
fied leaflets. ${ }^{5,6}$

As newer procedures become commercially available to treat valvular heart disease, it is important to realize that the cardiac surgeon sits at the nexus of these technologies, a critical member of the heart team, perfectly positioned to evaluate patient factors such as age and risk for surgical intervention and anatomic factors such as left ventricular outflow tract size and calcium and ideally suited to choose the best therapy for an individual patient. As Capestro and colleagues have demonstrated, surgeon awareness of these newer technologies and their strengths and weaknesses will yield the best results for our patients.

\section{References}

1. Capestro F, Massaccesi S, Matteucci MLS, Torracca L. Sutureless aortic valve prosthesis in a calcified homograft. J Thorac Cardiovasc Surg. 2015;150: e29-30.

2. Joudinaud TM, Baron F, Raffoul R, Pagis B, Vergnat M, Parisot C, et al. Redo aortic root surgery for failure of an aortic homograft is a major technical challenge. Eur J Cardiothorac Surg. 2008;33:989-94.

3. Khalpey Z, Borstlap W, Myers PO, Schmitto JD, McGurk S, Maloney A, et al. The valve-in-valve operation for aortic homograft dysfunction: a better option. Ann Thorac Surg. 2012;94:731-6; discussion 735-6.

4. Duncan A, Davies S, Di Mario C, Moat N. Valve-in-valve transcatheter aortic valve implantation for failing surgical aortic stentless bioprosthetic valves: a single-center experience. J Thorac Cardiovasc Surg. 2015;150:91-8.

5. Villa E, Messina A, Cirillo M, Brunelli F, Mhagna Z, Dalla Tomba M, et al Perceval sutureless valve in Freestyle root: new surgical valve-in-valve therapy. Ann Thorac Surg. 2013;96:e155-7.

6. Folliguet TA, Laborde F. Sutureless Perceval aortic valve replacement in aortic homograft. Ann Thorac Surg. 2013;96:1866-8.

\footnotetext{
From the Department of Surgery, Washington University in Saint Louis School of Medicine, St Louis, Mo.

Disclosures: Author has nothing to disclose with regard to commercial support.

Received for publication May 23, 2015; accepted for publication May 26, 2015; available ahead of print July 22, 2015.

Address for reprints: Hersh Maniar, MD, Department of Surgery, Washington University School of Medicine, 1 Barnes Jewish Hospital Plaza, Queeny Tower 3108, St Louis, MO 63110 (E-mail: maniarh@wudosis.wustl.edu).

J Thorac Cardiovasc Surg 2015;150:e31

$0022-5223 / \$ 36.00$

Copyright (c) 2015 by The American Association for Thoracic Surgery

http://dx.doi.org/10.1016/j.jtcvs.2015.05.062
} 